\title{
AJANKOHTAISTA RUOTSIN AIKUISKASVATUKSESTA
}

\author{
T apaa sivistystyö on myös Ruotsissa saanut mukautua \\ niukkeneviin yhteiskunnan varoihin samalla, kun jakajien \\ määrä on ollut nousussa ja keskinäinen kilpailu lisääntynyt. \\ Opintokeskukset ovat sen vuoksi käyneet kiivastakin keskustelua \\ tulevaisuudestaan ja tavoitteistaan.
}

Vapaan sivistystyön valtionapujärjestelmä on muuttumassa ratkaisevasti: kukin opintokeskus saa vastaisuudessa käyttää valtionapunsa vapaasti omiin tavoitteisiinsa. Arvio varojenkäytön onnistumisesta tehdään jälkikäteen ja tulokset ovat pohjana seuraavalle rahanjaolle.

Ruotsin aikuiskoulutusta uudistettaessa vapaan sivistystyön organisaatiot korostavat omaa erityisluonnettaan. Tavoitekeskusteluissa on noussut voimakkaasti esiin koulutuksellisesti syrjäytyneiden tarpeet, siirtolaiset sekä kehitysyhteistyö.

K ertomuksessani viime vuosien tapahtumista Ruotsissa annan lyhyen yleiskatsauksen Folkbildningsförbundetista (Ruotsin vapaan sivistystyön yhteisjärjestöstä).

Folkbildningsförbundet on 11 opintokeskuksen yhteistyöelin. Mutta myös erilaisten kansanliikkeitten kansanopistot - noin puolet Ruotsin kansanopistoista - ovat etujärjestönsä RIO:n välityksellä sen jäseniä, samoin maan kirjastot yhteisjärjestönsä Sveriges allmänna biblioteksföreningenin kautta.

Folkbildningsförbundetilla on myös alueellinen toimisto joka läänissä - länsbildningsförbund/lääninsivistysjärjestö - jolla on valtakunnallista järjestöä vastaava rakenne ja palkattu henkilökunta.

Folkbildningsförbundetin toiminnalle on ominaista ennen kaikkea yhteistyö, neuvottelu, tiedotus ja mielipiteitä muokkaava työ 11 opintokeskuksen puolesta ja huomattavasti vähäisemmässä määrin kansanopistojen ja kirjastojen asioitten hoito. Siksi tämä yleiskatsaus käsittelee pääasiassa opintokeskusten tilannetta ja sitä keskustelua, jota me käymme Ruotsissa.

Folkbildningsförbundetin tärkein tehtävä opintokeskusten näkökulmasta katsottuna — on toimia vapaan sivistystyön yhteisenä foorumina yhteyksissä eri viranomaisiin sekä hallitukseen ja eduskuntaan.

Viime vuosien aikana Folkbildningsförbundet on enenevässä määrin toiminut työmarkkinaneuvotteluissa opintokeskuksia edustavana neuvotteluosapuolena opintokerhojen vetäjien ammattijärjestöjen kanssa.

V uonna 1986 pidetyn Pohjoismaisen kansansivistyskokouksen aikoihin olivat opintokeskukset taloudellisessa kriisissä ja Ruotsissa levisi pessimismi vapaan sivistystyön tulevaisuuden suhteen. Se kriisi on - ainakin toistaiseksi voitettu ja usko tulevaisuuteen ja itseluottamus 90-luvun haasteiden edessä on nyt erittäin vahva.

Kriiseistä ja vaivoista kasvaa, kuten historia on usein osoittanut, tieto ja kyky muutokseen ja 
uudistumiseen. Minusta Ruotsin opintokeskukset ovat kokeneet ja kokevat parhaillaan sellaisen muutosprosessin. Toiminnan suhteen ei muuten koskaan ole ollutkaan mitään kriisiä - vain tulot ja menot eivät ole olleet tasan. Toiminta on siitä syystä ollut hyvin tappiollista.

Syitä 80-luvun taloudellisiin vaikeuksiin on monia.

Silloinen porvarihallitus aloitti 1981 uuden opintokerhotoiminnan valtionapujärjestelmän. Se oli rakenteeltaan parempi kuin aikaisempi systeemi, koska siinä käytettiin kaavamaisia valtionapuja, mutta se merkitsi valtion koko avustussumman leikkaamista samalla, kun asetettiin katto kerhotoiminnan laajenemiselle. Opintokeskusten ei sallittaisi lisätä toimintaansa.

Samalla valtionavun rakenne on sellainen, että opintokeskusten on toimittava urakkasysteemissä toistensa kanssa kilpaillen. Säilyttääkseen suhteelliset osuutensa valtionavusta on jokaisen opintokeskuksen pakko pitää toimintansa määrällisesti samalla tasolla tai lisätä sitä.

$\int^{a}$ toiminta on lisääntynyt koko 80-luvun. Sen voimakkaan vähentymisen jälkeen, lähes $1 / 3$ toiminnasta, joka tapahtui, kun uusi järjestelmä aloitettiin 80-luvun alussa, on toiminta kokonaisuutena jälleen kasvanut. Nyt se on suurin piirtein yhtä laajaa kuin suurimmillaan 70-luvun lopussa.

Ruotsiin on myös syntynyt uusi opintokeskus 80-luvulla. Urheiluliike on perustanut oman opintokeskuksen nimeltä SISU. Valtio ei ole kuitenkaan myöntänyt mitään lisäystä tuntimääriin tai määrärahoihin tämän uuden opintokeskuksen perustamisen myötä. SISU pyrkii vakiinnuttamaan asemansa kilpailussa aikaisempien 10 opintokeskuksen kanssa muuttumattomien määrärahojen puitteissa. Vaaditaan todella suomalaista sisua selviytyä sellaisessa tilanteessa.

Tämä tilanne rinnastuu kansanopistojen vastaavaan. Uusia kansanopistoja perustetaan silloin tällöin. Jälleen ovat jotkin järjestöt ilmoittaneet kiinnostuksensa kansanopiston perustamiseen. Kun sellaisia on syntynyt, valtio ei ole lisännyt kansanopistojen yhteismäärärahaa. Se merkitsee käytännössä, että olemassaolevat kansanopistot ovat joutuneet osallistumaan uuden rahoitukseen luopumalla osasta yhteistä määrärahaa. Valtionavun tosiasiallinen supistaminen on jatkunut vielä silloinkin, kun meillä on ollut sosiaalidemokraattinen hallitusvalta Ruotsissa - vuodesta 1982.
Ne hyvin voimakkaat säästötoimet, joihin ryhdyttiin julkisella sektorilla valtion budjettialijäämän pienentämiseksi, eivät kuitenkaan aiheuttaneet vapaan sivistystyön määrärahojen suoria vähennyksiä - toisin kuin esimerkiksi Norjassa - muuta kuin edellä esitetyssä tapauksessa 80-luvun alussa.

Mutta talous on kuitenkin supistunut vuosi vuodelta johtuen siitä, että valtionavun neljän prosentin lisäys on ollut pienempi kuin kustannusten nousu palkoissa ja hinnoissa.

$\mathbf{V}$ astaava supistus on muuten tapahtunut myös kunnallisissa määrärahoissa. Opintokeskuksille ne merkitsevät lähes yhtä paljon kuin valtion määrärahat.

Haluan huomauttaa, että eräs parhaillaan nähtävillä oleva uhkakuva on kunnallisten avustusten kehitys. Kuntien taloudellinen tilanne on tällä hetkellä hyvin hankala.

Kunnilla on ollut hyvin voimakasta kustannusten nousua, ennen kaikkea kalliin palkkaratkaisun vuoksi samalla, kun hallitus on ehdottanut kunnallisveron nousun pysäyttämistä lähivuosiksi.

Kaikkien kuntien on pakko säästää voimakkaasti. Koska on pakko asettaa etusijalle lasten ja nuorten koulu, sairaanhoito ja lasten ja vanhusten hoito, vapaata sivistystyötä ja kulttuuritoimintaa tullaan leikkaamaan voimakkaasti.

K uten sanoin aiemmin, 80-luvun talouskriisin syitä on monia.

Yksi on toiminnan kasvu, jota vastaavaa tuntimäärien lisäystä valtio ei myöntänyt. Toinen jo kuvaamani on kustannusten kasvu, jota vastaavaa valtionavun lisäystä ei saatu.

Sen lisäksi monet opintokeskukset olivat suuren menestyksen vuosina 70-luvun lopulla kasvaneet "pukukokoon" joka osoittautui liian suureksi talouden tiuketessa. Opintokeskukset eivät olleet valmistautuneet uuteen tilanteeseen ja joutuivat kriisiin.

Viime vuosina on monilla toimilla pyritty parantamaan talousongelmia. Opintokeskukset ovat rationalisoineet hallintoaan, henkilökuntaa on sanottu irti, on luovuttu kalliista toimitiloista. Kurssimaksuja on nostettu huomattavasti ja jäsenjärjestöille tarkoitetun toiminnan puitteissa on sovittu, että kerhonvetäjille ei makseta enää palkkioita. He toimivat siis suuressa määrin aatteellisella pohjalla. 
Samalla kun on yritetty nousta kriisistä, on $S$ monissa opintokeskuksissa käyty kiihkeää keskustelua tulevaisuudesta. On määritelty tavoitteita ja täsmennetty omaa osuutta ja tehtäviä vapaan sivistystyön ja kulttuurin kentässä 90-luvun yhteiskunnassa.

Valtionapukriisiä ratkaisemaan ja tulevaisuuden yleiset vapaan sivistystyön tavoitteita määrittelemään Ruotsin opintokerhotoimintaa valvova viranomainen, skolöverstyrelsen (kouluylihallitus), asetti selvitystyöryhmän, joka esitti ehdotuksensa kaksi ja puoli vuotta sitten.

(Opintokeskusten hyvin laajan kulttuuritoiminnan, valtionapu noin 130 miljoonaa kruunua, valvontaviranomainen on toinen, nimittäin Statens Kulturråd, Valtion Kulttuurineuvosto.)

Kouluylihallitus ehdotti selvityksessään siirtymistä nykyisestä ohjeisiin ja volyymiin perustuvasta valtionapusysteemistä tavoiteperusteiseen valtionapuun. Tai ilmaistakseni asian ytimekkäämmin kukin opintokeskus saa kasan rahaa, jotka se saa vapaasti käyttää työskennelläkseen niiden erityisten tavoitteiden saavuttamiseksi, jotka ne omista perusarvoistaan tai kiinnostuksistaan kiteyttävät. Sitten yhteiskunta yhdessä opintokeskusten kanssa arvioi, miten asetetut tavoitteet on onnistuttu saavuttamaan. Tämä arviointi on sitten vastaisen opintokeskusten valtionapujaon pohjana.

Ymmärtääkseen tämän keskustelun se täytyy asettaa suurempiin yhteyksiin.

Ensiksi, hallitus ja eduskunta ovat siirtymässä kolmivuotiseen budjettikauteen suurissa osissa valtion toimintaa. Se on hyvä, myös vapaalle sivistystyölle. Saamme pitemmän taloussuunnittelujakson, jos tiedämme puitteet kolmeksi vuodeksi eteenpäin.

Toiseksi, suuri osa valtion toiminnan ohjauksesta muuttuu, samoin valtionavun perusteet yksityiskohtaisesta ohjeisto-ohjauksesta tavoiteohjaukseksi. Sama kehitys on muuten meneillään myös elinkeinoelämässä ja muussa julkisessa hallinnossa, esimerkiksi kunnissa.

Puhutaan myös hajauttamisesta, pienimuotoisuudesta, tulosyksiköistä ja tulosvastuusta tavoiteohjatun toiminnan puitteissa. Opintokeskukset olivat varsin tyytyväisiä tähän ehdotukseen, kun se esiteltiin. Sittemmin on kuitenkin herännyt epäilys. Se perustuu pääasiassa siihen, että toistaiseksi ei ole olemassa kehittyneitä metodeja vapaan sivistystyön eikä opintokeskusten edistämän kulttuurin arvioimiseksi.

T apaata sivistystyötä ja kulttuuria ei voi eikä saa rinnastaa tai verrata arvioinnissa esimerkiksi yleiseen koulujärjestelmään tiukkoine oppiennätyksineen, todistuksineen ym.

Tulevaisuuskeskustelu onkin ottanut uutta tulta opintokeskuksissa. Se johtuu siitä, että opetusministeriö on ilmoittanut antavansa aikuiskoulutusesityksen helmikuussa 1991. (Ks. Abrahamsson sivu 99) Se käsittelee kunnallista aikuiskoulutusta (KOMVUX ja GRUNDVUX, kuten ne lyhennetään Ruotsissa). Esitys käsittelee myös kansanopiston roolia 90-luvulla. Sitä on pohtinut erityinen valtion selvityskomitea. (Mietinnöt on annettu syksyllä 1990, ks. Abrahamsson, sivu .99)

Esitys käsittelee henkilöstökoulutusta ja kompetenssin kehittymistä elinkeinoelämässä ja hallinnossa laajassa mielessä ja tekee esityksiä tavoite- ja rajanvetokysymyksissä sekä mahdollisissa valtionapusysteemin muutoksissa opintokeskusten toiminnan suhteen.

Opintokeskuksia on tässä mielessä hallinnollisesti pidetty osana Ruotsin aikuiskoulutusjärjestelmää 70-luvulta lähtien. Opintokeskusten sisällä on olemassa erilaisia mielipiteitä siitä, onko vapaan sivistystyön erityisluonne, josta kaikki olemme yksimielisiä, vaarassa kadota tällaisessa tilanteessa.

Opintokeskukset laativat Studieförbundetin johdolla yhteisen näkemyksen vapaan sivistystyön asemasta 90-luvulla sekä tekivät ehdotuksia valtionapujärjestelmän muutoksiksi. Ehdotukset jätettiin opetusministeriön esitystyön pohjaksi. Eräät opintokeskukset ovat antaneet myös omat lausuntonsa, joissa ne korostavat tiettyjä asioita, joista niillä on eri käsitys, tai jossa ne ovat painottaneet eri alueita kuin yleispaperissa.

Olemme nostaneet keskeisesti esiin vapaan sivistystyön erityisluonteen suhteessa yhteiskunnan järjestämään aikuiskoulutukseen tai maksupalvelutyyppiseen henkilöstökoulutukseen. Olemme vakuuttuneita siitä, että vapaa sivistystyö sekä meidän edustamamme tietokäsitys ovat 90-luvun tieto- ja informaatioyhteiskunnassa tarpeellisempia kuin konsanaan.

Opintokeskusten hyvin yksimielisen näkemyksen mukaisesti meillä on aikuiskoulutuksessa erityistehtävänä täyttää tietoaukkoja. Tiedämme hyvin, että nämä kuilut eivät kutistu, vaan päinvastoin laajenevat tulevaisuuden tietoyhteiskunnassa. 
T iedämme myös, että yhteiskunnan aikuiskoulutus on epäonnistunut pyrkiessään tavoittamaan vähän koulutetut. Opintokeskuksilla on tässä suhteessa paljon paremmat mahdollisuudet, koska niillä on soveltuvammat metodit ja pedagoginen näkemys. Ehdotamme siis, että valtio kannustaisi opintokeskuksia toimimaan yhdessä aikuiskoulutuksen suuremman oikeudenmukaisuuden turvaamiseksi suuntaamalla valtionapujen jakoa.

Sama tilanne vallitsee myös kulttuurissa. Tiedämme, että laitospohjainen kulttuuritoiminta tavoittaa vain kolme kymmenestä. Vapaan sivistystyön tehtävänä täytyy olla ne seitsemän, jotka tänä päivänä jäävät kulttuuritoiminnan tai kulttuurielämysten ulkopuolelle. Tässä on myös kysymys oikeudenmukaisuudesta.

Ja opintokeskukset onnistuvat aika hyvin näiden seitsemän tavoittamisessa. Lähes 100000 ihmistä osallistuu vuosittain opintokeskusten kulttuuritoimintaan. Opintokeskusten kulttuuriohjelman puitteissa tavoitetaan sen eri muodoissa 10 miljoonaa osallistujaa vuosittain.

Eräs kysymys, joka on saanut aivan liian suuren huomion viime vuosien keskustelussa on opintokeskusten osallistuminen maksupalvelukoulutukseen. Maksupalvelutoiminta on - ja luulen että se sellaisena pysyykin - hyvin rajallista myös 90-luvulla opintokeskusten osalta siitä huolimatta, että markkina-ajattelu yhä enemmän alkaa ilmetä myös Ruotsin poliittisessa keskustelussa.

Folkbildningsförbundetin paperissa olemme selvästi painottaneet, että käyvät valtion- ja kunnanavut eivät voi kohdistua - niin kuin nyt maksupalvelutoimintaan. Muuten kukin opintokeskus itse ratkaisee haluaako se osallistua laajaan ja kasvavaan henkilöstökoulutukseen. Jotkut opintokeskukset ovat päättäneet, että jos meidän jäsenemme, kuten esimerkiksi ammattiyhdistykset, katsovat meillä olevan syytä olla mukana henkilöstökoulutuksessa voidaksemme antaa myös sille vapaan sivistystyön leiman, silloin se on 90-luvun selkeä tehtävä. Tätä mieltä on mm. edustamani ABF (Arbetarnas Bildningsförbund).

pintokeskuksilla on Ruotsissa laaja ja monipuolinen ohjelma. Suurimmalla osalla keskuksista on kansanliiketausta. Itsestään selvä tehtävä 90-luvulla on toimia liikkeiden virkistämiseksi ja uudistamiseksi, sekä vanhojen vakiintuneiden liikkeiden että uusien esiin nousevien.
Meidän tulee varjella ja kehittää pohjoismaisen demokraattisen mallin ainutlaatuista piirrettä, nimittäin ihmisten osallistumista yhteiskunnan kehitykseen kansanliikkeillä.

Ehdotamme uuden kehitysmäärärahan lisäämistä opintokeskuksille, jotta voitaisiin luoda mahdollisuus vapaamuotoisemmin uudistaa ja kehittää sekä kansanliiketyötä että muuta sivistys- ja kulttuuritoimintaa. Kehitysmääräraha voitaisiin kohdistaa siten, että kukin opintokeskus itse yleisten vapaan sivistystyön tavoitteiden puitteissa saisi käyttää rahaa vapaasti omista painopistealueistaan lähtien. Se voi olla alku vähitellen merkittävämmälle muutokselle kohti tavoitesuunnattua valtionapujärjestelmää.

Monilla opintokeskuksilla on hyvin laajaa vammais- ja siirtolaistoimintaa. Näillä alueilla näemme vapaan sivistystyön kasvavan tarpeen 90-luvulla. Valtionapujen vammaisille tarkoitetut lisämäärärahat haluamme tietenkin säilyttää ja mieluiten kehittää. Siirtolaistyön piristämiseksi haluaisimme lisätä uuden avustuksen. Opintokeskusten velvollisuus on työskennellä myös siirtolaiskysymysten parissa.

Meillä on pitkä traditio opettaa ruotsia siirtolaisille. Tätä toimintaa muutetaan vuodesta 1991 lähtien siten, että kunnat ovat vastuussa koko SFI-toiminnasta (svenska för invandrare $=$ ruotsia siirtolaisille). Se on ollut valitettavasti hajallaan. Mutta opintokeskukset ovat toivottavasti myös jatkossa toivottavasti mukana järjestämässä tätä koulutusta.

Läheisesti siirtolaiskysymyksiin liittyvät kansainväliset kysymykset laajemminkin. Kansainvälinen kiinnostuneisuus on opintokeskuksissa lisääntynyt dramaattisesti viime vuosina, ei vain tiedotuksena näistä kysymyksistä, vaan ennen kaikkea laajana erilaisten kehitysprojektien kirjona. Valtion kehitysapuelin SIDAlla on määrärahat erityisesti opintokeskusten käyttöön omavastuuosuutta vastaavasti.

Folkbildningsförbundetin ja opintokeskusten osalta siirrymme 90-luvulle luottaen itseemme ja uskoen, että vapaa sivistystyö on välttämättömämpää kuin koskaan. Meidän vain täytyy saada poliitikot, viranomaiset ja muut päätöksentekijät vakuuttuneiksi siitä, että meitä tarvitaan ja että meillä on tietty tehtävä, jollei muuten niin ottamalla itsellemme tehtäviä ja käytännön konkreettisella toiminnalla osoittaa oma kuolemattomuutemme. 